\title{
Dynamic Land Resources Management at the Mount Kelud, Indonesia
}

\author{
Puspita Indra Wardhani ${ }^{*, 1}$, Junun Sartohadi ${ }^{2}$, Sunarto ${ }^{2}$ \\ ${ }^{1}$ Doctoral Program of Geography, Faculty of Geography, Universitas Gadjah Mada \\ ${ }^{2}$ Faculty of Geography, Universitas Gadjah Mada \\ * Corresponding Author (e-mail: poespita.indra@gmail.com)
}

Received: 09 March 2017 / Accepted: 05 May 2017 / Published: 01 July 2017

\begin{abstract}
There is a contradictive situation between the theory that believes that high volcanic hazard areas should be for limited production zones and those areas that are intensively utilised for several production activities. This paper tries to discuss that contradictive situation from both the perspective of natural hazards and natural resources, therefore, the best options for the land utilisation pattern might be formulated at these high volcanic hazards areas. We conducted landscape analysis that covers volcanic morphology, volcanic materials, and both natural and artificial processes that modify the morphology and materials characteristics. The natural processes occurring in the high volcanic hazard might cover non-volcanic processes such as erosion and landslide. The artificial processes were usually considered as land utilisation activities by the local community. In such areas where both natural and artificial processes occurred, we conducted in-depth interviews to assess the community perception on thread and benefits of the last Kelud Eruption in February 2014. We evaluated the current land resources utilisation and portrayed the local adaptive land resource utilisation. There were three types of land resources available at the active volcano: space, natural scenery, and volcanic materials. The availability of these land resources was in a dynamic condition both in terms of quality and quantity. Immediately after the eruption, the natural scenery made the area attractive as a tourist destination. Following the high intensity of rainfall, the volcanic materials might be used as high-quality construction materials. The available space might be utilised for any purposes after the situation became relatively stable. The current space was mostly used for agricultural enterprises which accommodates the physical and socio-cultural characteristics of the active volcano environment.
\end{abstract}

Keywords: volcano, land, resources, management, Mount Kelud.

Abstrak. Terdapat situasi kontradiktifantara teori yang mengatakan bahwa kawasan gunungapi dengan tingkat bahaya yang tinggi harus digunakan untuk zona produksi terbatas, namun pada kenyataannya wilayah tersebut digunakan secara intensif untuk beberapa kegiatan pertanian. Penelitian ini mencoba untuk membahas situasi kontradiktif dari kedua perspektif, bencana alam dan sumberdaya alam, oleh karena itu, pola pemanfaatan lahan menjadi pilihan terbaik yang dapat diformulasikan pada kawasan gunungapi dengan tingkat bahaya yang tinggi. Kami melakukan analisis bentanglahan yang mencakup morfologi permukaan gunungapi, material gunungapi, dan proses alami dan buatan yang memodifikasi morfologi dan karakteristik material. Proses alami yang terjadi pada kawasan gunungapi dengan tingkat bahaya yang tinggi mencakup proses diluar erupsi seperti erosi dan tanah longsor. Proses buatan biasanya ditemukan sebagai kegiatan pemanfaatan lahan oleh masyarakat setempat. Pada area dimana proses alami dan buatan terjadi, kami melakukan wawancara mendalam untuk menilai persepsi masyarakat tentang ancaman bahaya dan manfaat letusan Kelud terakhir pada bulan Februari 2014. Kami mengevaluasi pemanfaatan sumber daya lahan saat ini dan potret pemanfaatan sumber daya berdasarkan adaptasi masyarakat lokal. Terdapat tiga jenis sumber daya lahan yang tersedia di gunungapi aktif, yaitu: ruang, pemandangan alam, dan material gunungapi. Ketersediaan sumber daya lahan tersebut dalam kondisi dinamis baik dari segi kualitas maupun kuantitas. Setelah erupsi Kelud, pemandangan alam segera menjadi objek yang paling menarik untuk tujuan wisata. Periode berikutnya setelah intensitas curah hujan tinggi, material 
gunungapi (pasir dan batu) dimanfaatkan sebagai bahan bangunan berkualitas tinggi. Ruang yang tersedia dapat dimanfaatkan untuk tujuan apapun setelah situasinya menjadi stabil. Pemanfaatan ruang saat ini sebagian besar merupakan perusahaan perkebunan yang mengakomodasi karakteristik fisik dan sosial-budaya dari lingkungan gunungapi aktif.

Kata Kunci: gunungapi, lahan, sumberdaya, manajemen, Gunung Kelud.

\section{Introduction}

The Indonesian Government considers active volcanoes as areas with a high natural hazard threat. Therefore, such regions are treated as protected and/or limited production areas (Act No. 26 of 2007 on Spatial Planning and Act Ministry of Spatial Planning No. 21 / PRT / M / 2007 on Spatial Planning Guidelines for Volcanic Eruption and Earthquake). However, the real situations of land utilisation were completely different from the formal Act of Spatial Planning. The community living in the active volcanic areas intensively exploit the benefit of the available natural resources (Kelman and Mather, 2008; Bachri, 2015). The community considers volcanic eruptions as a part of their life, culture, and spirit (Wardhani, 2013; Bachri, 2015).

It is quite clear that the main reason behind the establishment of the Spatial Planning Act by the Indonesian Government is focused on the availability of high natural hazards with less consideration of the high potential of natural resources. The Indonesian Government had considered the volcanic eruption as an intangible threat and therefore, the community was instructed not to permanently occupy the areas near to the hazardous area (Bappenas,
2010). The abundant natural resources have not been considered as potential resources for improving the welfare of the people. However, in fact, the community is not concerned about the threat of natural hazards and pays more attention to utilising the abundant natural resources. This perception gap should be minimised so that the regional development, which is run by both the government and the local community, can obtain the expected results.

The communities living in the areas of active volcanoes are threatened by the continued risk of a volcanic eruption. It can happen at any time and has the potential to destroy everything located in the surrounding area. Naturally, a volcanic eruption causes serious damage, casualties, and loss of physical, economic, social and any other environmental components (Tilling and Lipman, 1993; Twigg, 2004; Marti and Ernst, 2005). Some examples of volcanic eruptions cases in Indonesia with such losses are presented in Table 1 . The risk of casualties, damage and losses from a volcanic eruption tends to increase with an increase in the population density and the diversity of economic activity in the community (Tilling, 2005).

Table 1. The Value of Loss, Damage and Fatalities from Volcanic Eruption in Indonesia in the period of 2010-2015.

\begin{tabular}{ccrr}
\hline Volcano & $\begin{array}{c}\text { Year of erup- } \\
\text { tion }\end{array}$ & $\begin{array}{c}\text { Total fatalities and } \\
\text { damages (IDR) }\end{array}$ & \multicolumn{2}{c}{ Loss of life } \\
\hline Merapi & 2010 & $154,950,390,000.000$ & 347 \\
Bromo & 2010 & $103,700,000,000$ & 0 \\
Sinabung & 2013 & $1,490,000,000,000$ & 15 \\
Kelud & 2014 & $1,000,000,000,000$ & 0 \\
\hline \multicolumn{4}{c}{ Source: BNPB (2014a, 2014a). }
\end{tabular}

Apart from the threat from volcanic eruptions, the areas with active volcanoes were blessed with abundant natural resources. Active volcanoes provide space, natural scenery and volcanic materials. Space is more limited today, and agriculture needs extensive space to develop. The land areas in and around active volcanoes which were used for agricultural activities are still extensive. The natural volcanic scenery has become one of the most 
popular destinations for tourist activity. Many tourists from the city are looking for natural scenes as a change from their daily activity. Volcanic material (sand and stone) became the most sought after building material due to the high level of development.

The study examines volcanic eruption of Mount (Mt.) Kelud in early 2014. The study chose the Mt. Kelud area after considering its intensity and explosive eruptions. Mt. Kelud is categorised as one of the active volcanoes with a relatively high population density. The land resource utilisation activities in the form of land use in the Mt. Kelud area are quite intensive. We may observe clearly that land resource utilisation activities take place from the peak up to the alluvial foot plain. There are three types of land resource utilisation: tourism, agriculture enterprises and sand mining. Mt. Kelud is categorised as one of the most dangerous active volcanoes in Indonesia due to its hot lahar flow and explosive eruptions. We attempted to provide some academic discussion on the unique regional management of coping with the abundant resources located at the high volcanic hazard areas. We might learn from local stakeholders in Mt. Kelud to utilise natural resources in the high volcanic hazard areas.

\section{Method}

\section{a. Study Area}

Mt. Kelud is $1700 \mathrm{~m}$ high and located in the East Java Province. The administrative area of this volcano covers three areas: Kediri Regency, Blitar Regency and Malang Regency (Figure 1). The surrounding area is inhabited by about 140,000 people spread from the middle slope to alluvial foot plains. Most of the people work as farmers in addition to other jobs such as trading and mining. Land in Mt. Kelud is mostly used for agricultural enterprises.

The complex of this volcano is also famous for tourism activities. The unique shape of the Crater Lake is a particular concern for nature tourism enthusiasts. Roads, toilets, and parking lots are well-built to support tourist facilities. Every year the number of visiting tourists continues to increase.

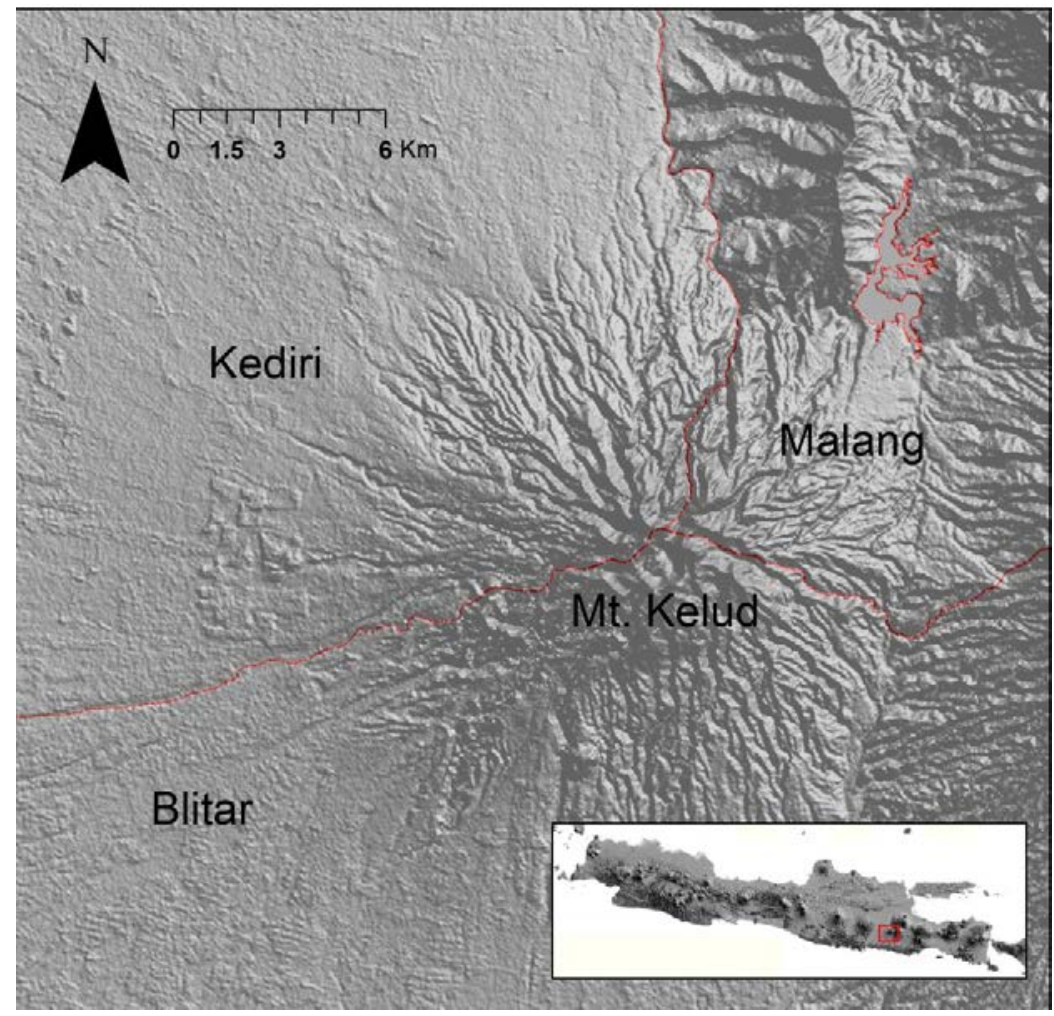

Figure 1. Study area of Mt. Kelud, East Java Province. 


\section{b. Field Survey}

The research has been conducted through field survey methods based on the descriptive observations of the physical environment and socio-cultural studies of the community. The field survey on the physical environment intends to stratify the volcanic body which starts from the peak to the fluvio-volcanic foot plain. Those volcanic body segmentations spatially correlate with the volcanic hazard intensity through both the data of the 2014 survey and the previous eruptions recorded by central and local government agencies. The survey on social aspects, which is based on the physical units at the volcanic body, aims to portray the social life of the community with a special emphasis on their livelihood.

\section{c. Analysis}

Landscape analysis is used in this research as an approach. Landscape analysis observes the cover volcanic morphology, volcanic materials and natural and artificial processes that affect morphological processes and material characteristics. The landscape analysis was conducted through field observation, sampling and in-depth interviews with local communities. Field observation of thelandscape analysis was completed from the peak down to the alluvial foot plain of Mt. Kelud.

The volcanic morphology is observed through altitude and slope differences. The volcanic material was observed on each volcanic relief. The distribution of the materials is mostly in the valleys of rivers which disgorge in Mt. Kelud. The natural and artificial processes were observed at different land covers and land use on each slope. Natural and artificial processes such as erosion and landslides affect morphological processes especially in volcanic areas with irregular reliefs. In-depth interviews with the local community were used to support related data on land use activities in Mt. Kelud area.

\section{Results}

\section{a. The Morphographic Arrangement of Mt.}

\section{Kelud}

The morphology of Mt. Kelud can be divided into five parts: volcanic cones, upper slope, middle slope, lower slope, and fluviovolcanic foot plain. The arrangement of the morphological body of a volcano describes the chronology of formation as well as the composing materials. The materials of the $\mathrm{Mt}$. Kelud body in various morphological units was characterised by the different sizes of the grains (Bourdier et al., 1997). The size of the materials at the high slope inclination ranges from mega-boulder and boulder, while at the lower inclination slopes are smaller, ranging from gravelly sand to silty sand. Some parts of the cone areas have a relatively high slope inclination approaching $90^{\circ}$ degrees because of its materials that consist of igneous rocks with an upright column structure.

The volcanic cone area does not perform as an ideal cone as a result of the past eruption events that are mostly explosive (Brotopuspito and Wahyudi, 2007). Igneous rocks that perform ridges around the crater formed the peaks of Mt. Kelud. These peaks have different names (Figure 2), such as Mt. Kelud (1731m), Mt. Gajahmungkur (1488m), Mt. Sumbing (1518m), Mt. Kombang (1514m), and Mt. Lirang $(1414 \mathrm{~m})$. There are relatively flat areas at the inter-peak areas that make them suitable for specific economic activities such as tourism. The peaks, the Crater Lake, and the hot water have become the natural tourist attractions.

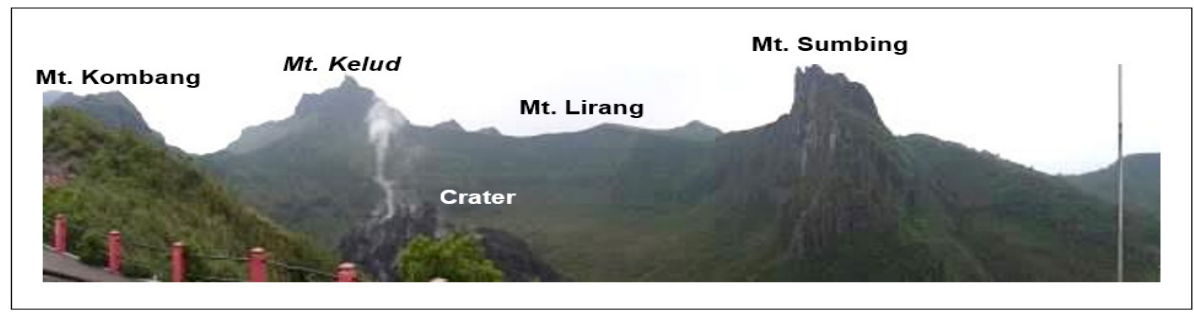

Figure 2. The irregular ridges that perform in the Mt. Kelud Peak. 
Sharp ridges inter-fingering with deep V-shape valleys characterise the upper slopes of Mt. Kelud. The weakly cemented unconsolidated pyroclastic materials dominate the upper slopes area. The surficial materials are commonly tuffs, breccia and lahar materials (Pratomo, 1997; Brotopuspito and Wahyudi, 2007). The upper slope has the highest volcanic hazard status as it always suffers from eruption activities, landslides and erosions. Such unconsolidated materials are easily moved downslope by water and/or gravitational actions to generate debris/lahar flow in the downslope areas (Thouret, 1998; Jeffrey et al., 2013). The upper slope of Mt. Kelud poses as protected forest. The dominant vegetation cover is shrubs and sparsely woody plants with small diameter. That typical land cover might be very much influenced by the brief eruption of Mt. Kelud. Therefore, an ideal tropical forest formation becomes impossible.

The middle slopes of Mt. Kelud have relatively wide ridges and rough undulating relief. The middle slopes are composed by U-shaped valleys with a large gradient and quite a high dissection density. Some of the valleys at the middle slope originated from the upper slope areas. Those valleys become the main path for lahar flow from the upper to the lower slopes. The hazard threat in the middle slope was still considered as relatively high and it should not permanently inhabited. The spouted pyroclastic materials from theexplosive eruptions falls in the middle slope and consists of materials with sizes ranging from gravel to coarse sand. The large particle of pyroclastic can be found at the bottom of the valley, gliding from the upper slope. Community activities that use natural resources are mostly concentrated in the grazing area was there is a commercial crops and tree plantations are limited. The intensive plantations are limited due to the presence of coarse pumice near the soil surface. However, there is a possibility that the trees may grow and become productive because pumice and tuff are easily weathered and have a high capability to hold nutrients and water.

The lower slope of Mt. Kelud has characteristics of medium undulating relief. It has a wider interfluve than the middle one. The river valley also becomes wider and shallower and that can make the water and/ or lahar flow shift to the adjacent valley during the flood. The fluvio-volcanic foot plain of Mt. Kelud lies with a flat or gently sloping relief. The fluvio-volcanic foot plains were formed by fluvial and gravitational processes dominated by lahar deposit material. The fluvio-volcanic foot plain of Mt. Kelud is extended to Brantas River (Maritimo et al., 2014). The fluviovolcanic foot plain is composed by materials of a finer size such as sand, silt and clay and a fluvial process transports these from volcanic materials located at the upper volcanic slope areas. The fluvio-volcanic foot plain is utilised as an intensive agriculture area as it receives an abundant water supply.

\section{b. Countermeasure structures to reduce hazards from Mt. Kelud Crater Lake}

The eruption of Mt. Kelud has the potential to create environmental damage and casualties. Reducing the hazard of Mt. Kelud eruption has become necessary. The oldest disaster management strategies in $\mathrm{Mt}$. Kelud ever recorded was the construction of the drainage canal in Srinjing Village at the time of the Ancient Mataram Kingdom (Arif, 2014) and is listed in Harinjing Inscription 804 $\mathrm{AD}$ (Figure 3). The construction of a drainage canal was intended to reduce the volume of water in Konto River so that the lahar would not overflow into the river bank and reduce the damage at agricultural areas (Dibyosaputro et al., 2015)

The Dutch Government in 1919 carried out the next disaster management strategy. The eruption of Mt. Kelud in 1919 had caused 5,160 casualties and extensive damage to plantations and agricultural land (Zaennudin, 2009). Based on the results of the Dutch 
Government research, the greatest danger of Mt. Kelud eruption was the primary lahar flow that directly related to the volume of the water in the crater (Zaennudin, 2009). The Dutch
Government constructed a drainage tunnel to reduce the amount of water in the crater to 2 million $\mathrm{m}^{3}$ (Zaennudin, 2009); see Figure 3.
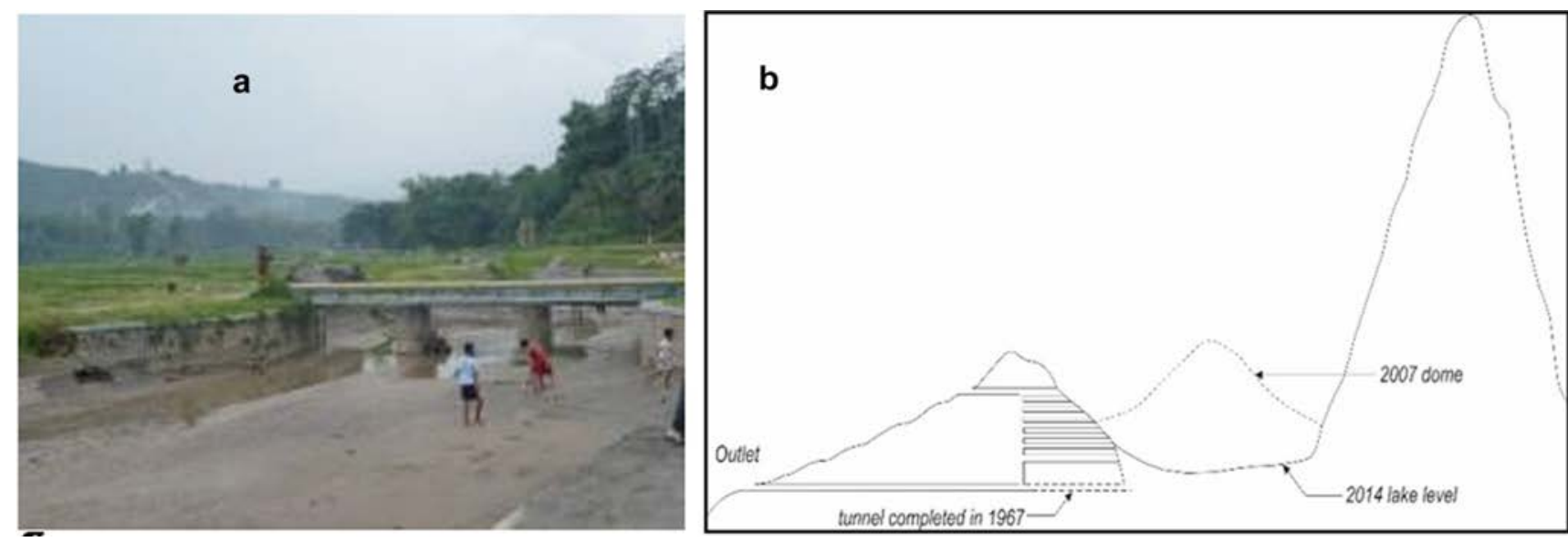

Figure 3. The Oldest Disaster Management in Mt. Kelud. (a) Srinjing River located in Siman Village, Kepung District of Kediri. Srinjing River is still functioning and is used to drain water from Srinjing River to Siman Reservoir and as irrigation canals for agricultural purposes, (b) drainage sketches in the crater of Mt. Kelud after the eruption in 2014.

The previous disaster management strategy was followed by the Indonesian Government who built the Sabo Dam along the rivers with headwater at the cone of Mt. Kelud. The Sabo dam construction aimed to impede the flow of lahar flood and the damages at the downstream. The construction project began in 1970 funded by the Japanese Government (Centres of Sabo, 2008). The Sabo dam was quite effective in impeding the lahar flow and had multi-functions as a bridge and irrigation protection (Centres of Sabo, 2008). The existence of the Sabo Dam makes easier to calculate the amount of lahar material.

\section{Discussion}

\section{a. Benefits and drawbacks of the volcanic eruptions}

The volcanic eruption has dramatically modified the environment through a single event. The extreme rapid changes of the environment have damaged several infrastructures and even life. Based on the impacts of a volcanic eruption, it is categorised as an extreme event, which is not yet well managed with the currently available technology. A volcanic eruption is one of the natural events that lead to disaster. The concept of disaster in Indonesia refers to the Hyogo Framework as the determination of functions of areas that also involves the hazard aspects (Bappenas, 2010).

A volcanic eruption is associated with disaster, as it has been recorded in human history that such eruptions could cause major damage and numerous casualties (Doocy et al., 2013). On the other side, active volcanic regions have become a centre of living for the community. Some experts claim that marginal communities, who do not have strong social capital, choose to live in high disaster-prone areas (Bryant, 1998). However, research by Bachri (2015) who took the case of humanvolcanoes in Bromo, produced the concept of open risk which explained that people were not only risking loss but also including physical, social, economic and spiritual benefits.

The case of the Mt. Kelud eruption in 2014 provides an illustration that the people enjoyed the benefits of a volcanic eruption. Mt. Kelud has long return period of eruption in terms of human life span, i.e. 15-35 years with a relatively short period of eruption event (Zaennudin, 2009). The last eruption in February 2014 happened in less than one hour. However, people could enjoy the abundant 
natural resources of Mt. Kelud up to 15-35 years later following that eruption. The community holds the greater value of benefits than the value of losses due to the eruption when it is viewed from the short duration of the eruption of Mt. Kelud.

The cases of benefits and losses due to the Mt. Kelud eruption are based on the results of surveys and simple calculations in the field. The results were described as follows:

1. The case of agricultural enterprise around the Mt. Kelud area

The middle up to the lower slope of Mt. Kelud area has developed as a plantation estate in Indonesia since the Dutch Colonisation. Mt. Kelud areas have been utilised for agricultural enterprise since 1830 until present. That means the agricultural activities have survived for 187 years and experienced 12 times as many eruptions like Mt. Kelud.

As a result of in-depth interviews with local people, Mt. Kelud eruptions did not significantly create a severe negative impact on the condition of agriculture at the slopes of Mt. Kelud. The crops were totally damaged due to the eruption of Mt. Kelud, yet within a period of 1 to 4 years, the plants grew well. Agricultural workers in the Mt. Kelud area are confident enough to make investments with a break-even period of 1 to 4 years, as they can expect the return in the form of crops for the next 15 years or more. The improved fertile land has become one of the benefits resulting from Mt. Kelud's eruption.

2. The case of tourism in Mt. Kelud

Mt. Kelud's eruption has created a special spot which attracts tourists, and the number of visitors has increased every year. This proves that there is no effect of the eruption to the decreasing of the number of tourists. In fact, the number of tourists visiting Mt. Kelud in 2014 (following the eruption) reached its highest number for the past 5 years (see Table 2). The Mt. Kelud eruption produced unique natural scenery, such as the view of the grey-coloured mountains and the standing burnt forest. The Mt. Kelud eruption also produced a pile of pyroclastic materials that encouraged some people to visit (Figure $4)$.

Table 2. Number of Visitors to Mt. Kelud in 2010-2014

\begin{tabular}{cc}
\hline Years & Visitors \\
\hline 2010 & 711,431 \\
2011 & 841,222 \\
2012 & 849,777 \\
2013 & $1,175,402$ \\
2014 & $1,286,914$ \\
Total & $4,864,746$
\end{tabular}

Source: Government of Tourism at Kediri District, 2015.

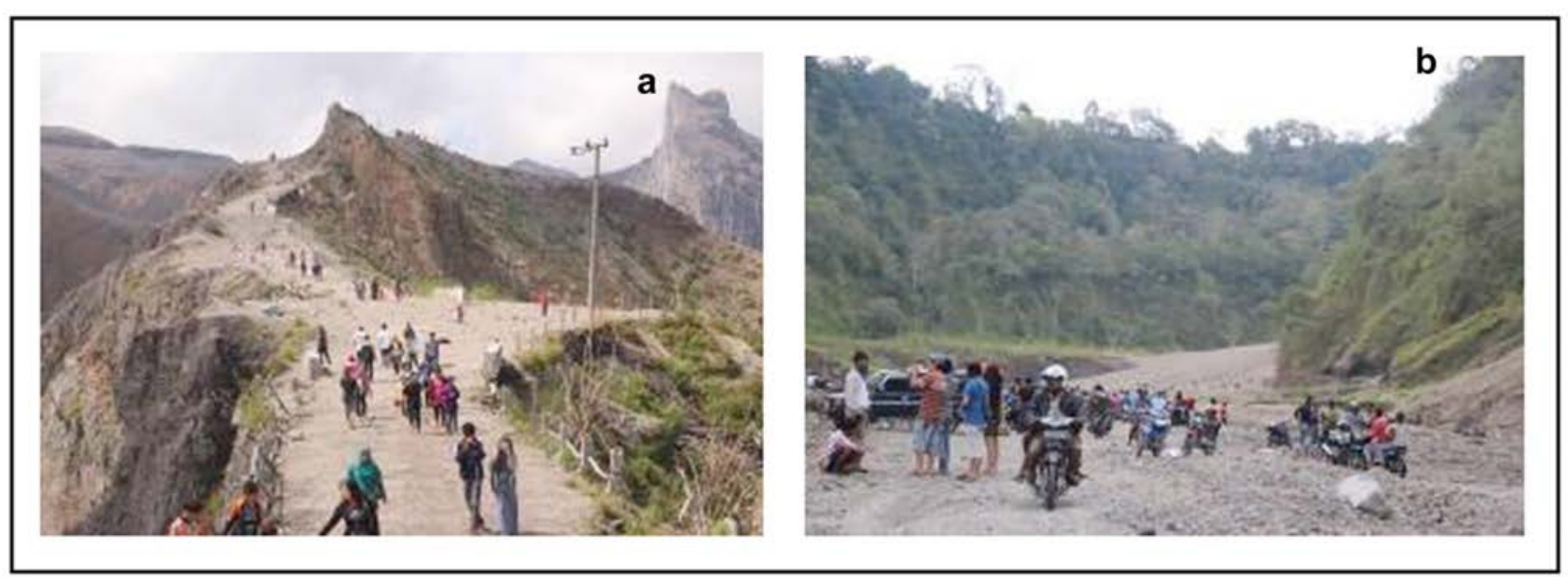

Figure 4. People want to visit Mt. Kelud after the 2014 eruption. (a) Landscape attraction formed in peak of Mt. Kelud; (b) Pumice sediment in the upstream of Kaliputih River. 
The remaining landscape of Mt. Kelud after its eruption was exquisite and probably can be seen only for a short period. Such a view could only exist for one or two years as long as the forest trees do not grow to cover the landscape. Piles of erupted materials can also be observed for a short time, which usually lasts only for few weeks before it is drifted away by the water flow during the rainy season. This typical landscape of volcanic eruption has become a different natural scene and, thus it has a potential to become a tourist attraction site (Dowling and Newsome, 2006; Cooper, 2010).

3. The case of the mining sector in Mt. Kelud The Mt. Kelud eruption provided benefits for some people who worked as sand miners in the rivers running from the peak of Mt. Kelud. The eruption ejected a huge amount of pyroclastic materials in the forms of ash, sand and rocks. The 2014 eruption generated a huge quantity of volcanic material as high-quality construction materials and for other purposes. The volcanic materials produced by Mt. Kelud reached 27.6 million $\mathrm{m}^{3}$ by 2014 and were deposited in the upstream of Bladak River. There were volcanic materials deposited at 12 other rivers that have not yet been calculated. The volcanic materials produced by the last eruption are quite special due to its composition of $91.82 \%$ pumice and $7.18 \%$ non-pumice.

The accumulated volcanic material in the rivers triggered the explosion of mining activities in almost all rivers flowing from $\mathrm{Mt}$. Kelud. Based on a recent field survey, there are at least 7 mining locations, such as Bladak, Kaliputih, Kicir, Sambong, Konto, Laharpang, and Ngobo Rivers. The most intensive mining activities occurred in Bladak River which runs continuously every day. On January $21^{\text {st }} 2016$, it was calculated that 606 trucks passed the exit road and this number could increase during the dry season. A simple calculation based on the number of trucks and the loading capacity of the truck, which is $6 \mathrm{~m}^{3}$ sand or $4 \mathrm{~m}^{3}$ stone, gives a figure of around IDR 145 million/day income for the local people. This is a better income compared to the other commodities from any other activities that are possible to run in such areas.

\section{b. Eruption is a blessing when we are ready, but would be a disaster if we are not ready.}

A spatially active volcano area has its own uniqueness that led to the diversity of the existence of land resources. The peak area of an active volcano has created several landform units. The diversity of land resources in the volcanic area is characterised by the transition of slope conditions, microclimate, land cover, and cover volcanic material types. The area of an active volcano should be spatially planned based on the availability of land resources so that it can provide the opportunity for the community to utilise the existing resources. The correct arrangement of land utilisation might be able to reduce eruption hazards for the local community (Becker, et al., 2010) who live in the lower slope areas.

Volcanic areas with limited production areas could be utilised as tourist destinations and by the agriculture and mining sectors. Space allocations for volcanic areas is based on the availability of resources that are scattered around the volcanic cone. It could be integrated with each other to provide more benefits to the community and reduce the exploitation of land resources for single activities. Space allocations for limited production in the volcanic area are tourism, agricultural enterprise, and mining.

\section{c. Tourism sector}

The tourism sector emphasises the uniqueness of the high dynamic landscape due to its eruption activities. Such a landscape could be found at the peak of the volcano and surrounding areas. The high dynamic landscape can be observed clearly when the eruption activities take place. Tourists may compare pictures of the landscape before and after the eruption using media available in the community. The landscape after the eruption is unique and will last for one or two years before 
the vegetation grows up. The uniqueness of the landscape and the time constraint to enjoy it can be used to boost tourist activity in Mt. Kelud.

In the future, the government and local communities may work together to manage the tourism sector. Tourism management is done by intensifying promotion through websites, TV, radio and newspapers to attract visitors. Scenarios of tourist attractions need to be prepared to prevent the accumulation of visitors. The setting can be done, for example, by introducing a cinema near to the tourist spot to maintain an adequate interval with the previous visitors. Another strategy to consider is providing alternative routes, i.e. the motorway or on foot. This option can be used to disperse the visitors into two alternative routes of their choice. The local government of Kediri District created large events at the peak areas during the low volcanic activities, and these events were also held following the eruption.

The number of visitors to Mt. Kelud has the potential to increase from time to time; this includes visitors associated with volcanic disaster education. The governments might work in collaboration with local communities to increase the market demand of Kelud tourism. The efforts may focus on providing multiple benefits for the tourists, including new educative materials about volcanic disaster management. The governments could provide training to the local community to act as tour guide for visitors.

\section{d. Agricultural sector}

Agricultural Enterprise was the first type of land utilisation activities to exploit the land resources at the Mt. Kelud region and was introduced by the Dutch. The allocated area for the agricultural enterprise is in the middle slope and lower slope and has two functions: a green barrier for the eruption hazard and agricultural production. The limited settlement was only developed for agricultural workers. The other factors considered in site selection for the agricultural enterprise are climate characteristic, chemical soil fertility and water availability.
The Mt. Kelud area has a mild climate with an average temperature of $24-26 \mathrm{C}$ and is suitable for cultivating several types of crops. Water is available throughout the year with an average rainfall of 3,700 $\mathrm{mm} /$ year which is sufficient to support optimum agricultural production. The Mt. Kelud area belongs to a slightly wet climate, which affects the high speed of soil material decompositions. The soil fertility of the Mt. Kelud area is chemically classified as fertile (Table3) based on the results of laboratory testing of soil samples taken from some layers in the soil profile (Figure $5)$. The pumice materials are categorised as high weatherable materials that release some inorganic chemical compounds to perform high base saturation soils. The only limitation is the low organic content which is relatively easy to improve through animal manuring. Therefore, agricultural activities should be combined with livestock activities so that the waste can be used for animal manure.

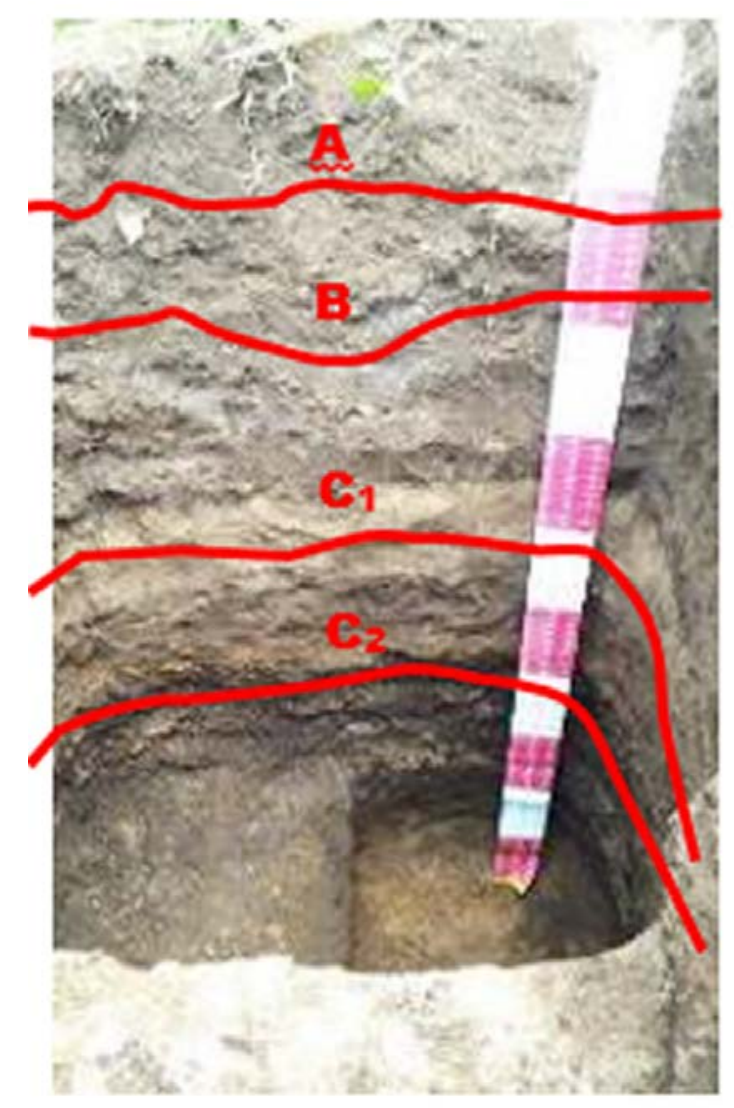

Figure 5. Soil Profile in The Gambar Agricultural Enterprise, Blitar, East Java. 
Table 3. Results of soil laboratory testing at Gambar Agricultural Enterprise

\begin{tabular}{lcccc}
\hline \multicolumn{1}{c}{ Horizon } & Ap & Bc & $\mathbf{C}_{1}$ & $\mathbf{C}_{2}$ \\
\hline Depth $(\mathrm{cm})$ & $0-25$ & $25-78$ & $78-110$ & $110-125$ \\
Colour matrix & $\frac{3}{4}$ & $\frac{2}{3}$ & $\frac{4}{3}$ & $\frac{3}{3}$ \\
Texture & $10 \mathrm{YR}$ & $10 \mathrm{YR}$ & $10 \mathrm{YR}$ & $10 \mathrm{YR}$ \\
Structure & $\begin{array}{c}\text { Loamy- } \\
\text { sand }\end{array}$ & $\begin{array}{c}\text { Loamy- } \\
\text { sand }\end{array}$ & $\begin{array}{c}\text { Loamy- } \\
\text { sand }\end{array}$ & Sand \\
Current pH & Granular & Granular & Massive & Single-grained \\
Organic Material & Moderate & Low & Low & Undetectable \\
DHL $(\mu \mathrm{mhos} / \mathrm{cm})$ & 1483 & 1660 & 1877 & 1413 \\
\hline
\end{tabular}

\section{e. Mining sector}

The mining sector has developed based on the availability of sand and pumice stone materials as a product of volcanic eruptions. Sand and pumice stone materials can be found anywhere on the volcanic slopes and the river valley becomes the easiest location to collect those materials through mining activities. The mining materials in the river valleys could come from direct air fall and slope transported materials from the adjacent areas. The morphology of river valley at the lower slope is wide and shallow meaning that vehicles could enter the sites to transport the mining materials.

The high demand of sand as construction materials has made its price increase from time to time. That situation has become a triggering factor for the mining activity to be more intensified and it may grow significantly which could threaten environmental sustainability. Therefore, an effort to create an added value of the mining product shall be made to suppress the number of up taking materials. Sand materials can be used as material for bricks, which is still very rare being produced by the community. With this activity, the adequate income can be maintained even though the number of material up taken already decreased.
Among the referral area for limited productions from the three sectors, the tourism sector can be considered to have the highest possibility to provide welfare for the community. It could also be combined with agriculture and mining sectors to improve the welfare of the community. The tourism sector will highlight the uniqueness of the area that can be used for limited cultivation. The uniqueness of a volcanic area is characterised by a difference of land use from the peak, upper slope, middle slope, lower slope to fluvio-volcanic foot plain. The process of land management and crop plantation will be a tourism attraction combined with the agricultural product and traditional food.

Tourism sector combined with the agriculture sector produces the natural attractions of exploring the agriculture area. Agricultural areas offer scenery that spans the diversity of agriculture crops, cool weather and agriculture processes which are considered as the selling point for tourism. The results of tourism activities are expected to increase the economic income of the farmers outside the agricultural sector. Tourism sector combined with the mining sector produce natural attractions and the exploration of mining sites add a touch of adrenaline for visitors (see Figure 6). 


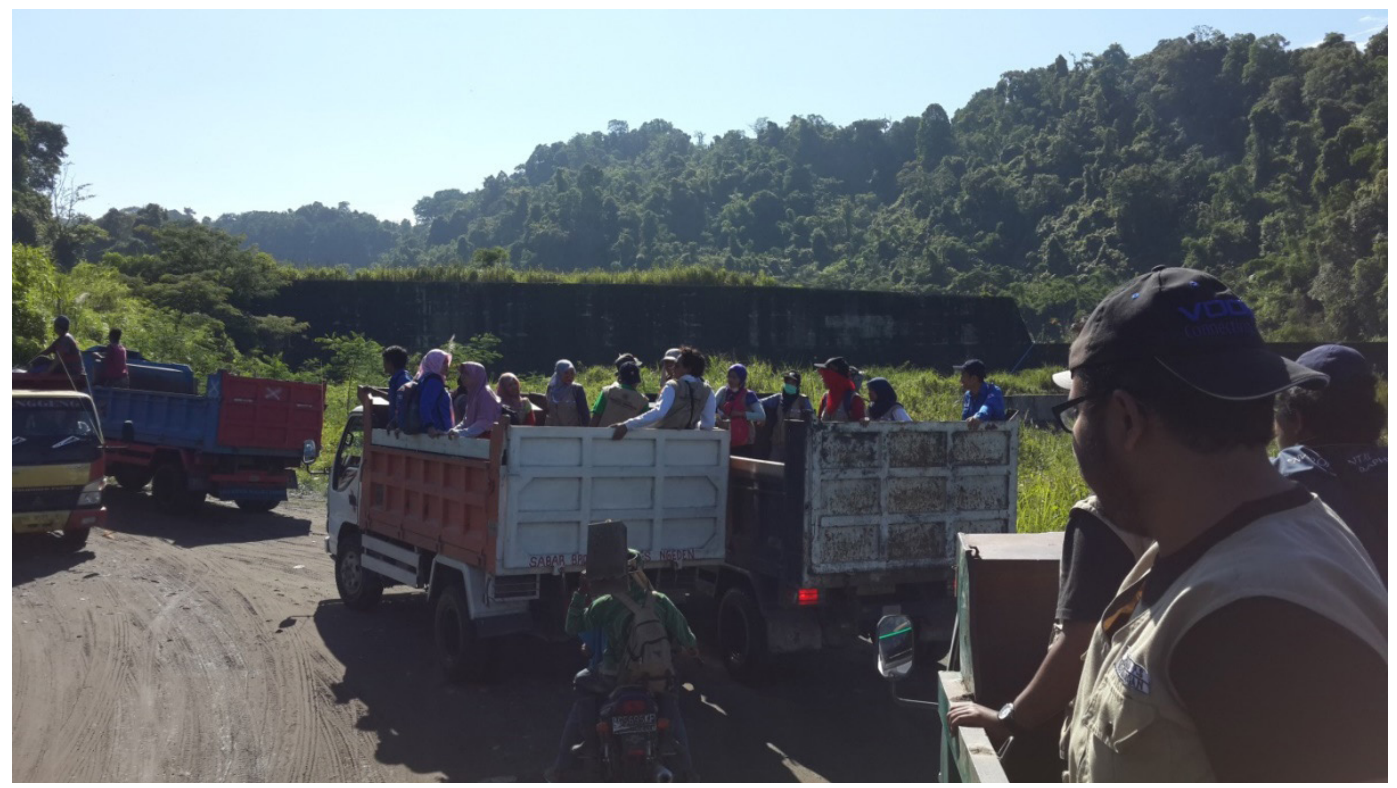

Figure 6. A new tourist attraction of the mining site.

Exploring the mining sites may require the cooperation of the sand truck drivers as this is a transportation mode to enter the mining sites. Visitors are offered a view of sand mining areas and the mining processes. The mining sector can earn extra income from tourist activities that can certainly improve the welfare of the community.

\section{Conclusion}

Land in the volcanic areas can be utilised by the local community. Land in a volcanic area should be arranged in such a way that it can accommodate two functions: an optimum opportunity for the local community to utilise existing resources and effective protection to the community from the volcanic hazard. There are three types of land resources available at the active volcano: space, natural scenery, and volcanic materials. The land resources might be directed for the development of the tourism sector, agricultural enterprise, and mining sectors.

The development of the tourism sector in the peak of a volcanic area should be based on the uniqueness of the dynamics of the natural landscape as a result of volcanic eruption. The development of the agriculture sector in the middle slope should be based on the climatic characteristics, chemical soil fertility, water availability and land availability. The development of the mining sector should be located on the lower slope by considering the sand and stone availability. The space allocation for mining is at the lower slopes considering the utilisation of the high quality of sand that has already been cleaned up from dirt and dust with the water flow.

The tourism sector is expected to become the sector most likely to provide welfare for the community when combined with the agriculture and mining sectors. The uniqueness of volcanic areas is not the only one that is located on the upper slopes and peaks but also at the spatial arrangement of land use that accommodates optimum resource utilisation and effective community protection. Mt. Kelud is unique in its spatial arrangement of land utilisation types, and it provides the best practices for other active volcano regions.

\section{Acknowledgements}

The authors are grateful to Universitas Gadjah Mada for their support during field survey as a part of this research and throughout the process of preparing the paper. The authors want to thank all colleagues, i.e. Alzaena Ulya Rusdimi, Anastasia Neni, Galih Aries and Listyo Yudha Irawan for their assistance during data collection in the Mt. Kelud area. We thank to all informants for their permission of photoaudio recording during interviews and paper 
publication. We also thank the local authorities at district level in East Java Province (Blitar, Kediri and Malang) especially Bapak Rijanto mayor of Blitar district; the CVGHM (Centre for Volcanology and Geological Hazard
Mitigation, Indonesia) especially Bapak Budi, Bapak Khoirul and Bapak Kuncoro; the BPBD (Regional Agency of Disaster Management) and Director of Gambar Plantation estate especially Bapak Kethut and Bapak Widodo.

\section{References}

Arif, A. (2014) Pelajaran dari Kelud. http:// nasional.kompas.com/read/2014/02/16/0916135/ Pelajaran.dari.Kelud. (Accessed January 16 ${ }^{\text {th }}, 2016$ ).

Bachri, S., Stötter, J., Monreal, M., \& Sartohadi, J. (2015) The calamity of eruptions, or an eruption of benefits? Mt. Bromo human-volcano system a case study of an open-risk perception. Natural Hazards and Earth System Science,15, pp. 277-290. doi: http://doi.org/10.5194/ nhess-15-277-2015.

Bappenas (2010) National Action Plan for Disaster Risk Reduction 2010-2012.

Becker, J.S., Saunders, W.S.A., Robertson, C.M., Leonard, G.S., \& Johnston, D.M.(2010). A synthesis of challenges and opportunities for reducing volcanic risk through land use planning in New Zealand. The Australasian Journal of Disaster and Trauma Studies, pp. 2010-1.

BNPB (2014a) Dampak Bencana terhadap Perekonomian Indonesia (Bagian 1). http:/ /www.bnpb. go.id/berita/1954/dampak-bencana-terhadap-ekonomi-indonesia-bagian-1. (Accessed January $\left.16^{\text {th }}, 2016\right)$.

BNPB (2014b) Dampak Bencana terhadap Perekonomian Indonesia (Bagian 2). http://www. bnpb.go.id/berita/1955/dampak-bencana-terhadap-ekonomi-indonesia-bagian-2. (Accessed January 16 ${ }^{\text {th }}, 2016$ ).

Bourdier, J.L., Pratomo, I., Thouret, JC., Boudon, G., \& Vincent, P. (1997) Observations, Stratigraphy and Eruptive Processes of The 1990 Eruption of Kelut Volcano Indonesia", Journal of Volcanonology and Geothermal Research, 79, pp.181-203.

Brotopuspito, K, S., \& Wahyudi (2007) Erupsi Gunungapi Kelud dan Nilai-B Gempabumi disekitarnya. Berkala MIPA, 17, pp. 47-56.

Bryant, R. L. (1998) Power, knowledge and political ecology in the third world: a review. Progress in Physical Geography, 22(1), 79-94. doi:10.1177/030913339802200104

Centres of Sabo (2016) Balai Sabo: Pusat Litbang Sumberdaya Air. http:/ / Saboresearchindonesia. blogspot.co.id/. (Accessed January $16^{\text {th }}, 2016$ ).

Dibyosaputro, S., Dipayana, G.A., Nugraha, H., Pratiwi, K., \& Valeda, H.P. (2015) Lahar at Kali Konto after the 2014 Eruption of Kelud Volcano, East Java: Impacts and Risk. Forum Geografi, Vol. 29 (1) July 2015, pp. 59-72.

Doocy, S., Daniels, A., Dooling, S., \& Gorokhovich, Y. (2013) The Human Impact of Volcanoes: a Historical Review of Events 1900-2009 and Systematic Literature Review. PLOS Currents Disasters (Edition 1), April 16 ${ }^{\text {th }}$,2013. doi: 10.1371/currents.dis.841859091a706efebf8a30f4e d7a1901.

Dowling, R., \& Newsome, D. (2006) Geotourism. Elsevier Butterworth Heinemann, London.

Erfurt-Cooper, P. (2010) Introduction, in : Erfurt-Cooper, P. \& Cooper, M. (Eds.), Volcano and Geothermal Tourism : Sustainable geo-Resources for Leisure and Recreation, Earthscan, Washington DC., pp. 1-3.

Jeffery, J., Gertisser, R., Troll, V.R., Jolis, E. M., Dahre, B., Harris, C., Tindle, A.G., Preece, K.,O'Driscoll, B., Humaida, H., \& Chadwick, J.P. (2013) The Pre-eruptive Magma Plumbing System of The 2007-2008 Dome-Forming Eruption of Kelud Volcano, East Java, Indonesia. 
Contributions to Mineralogy and Petrology, 166(1), 275-308. doi: http://doi.org/10.1007/ s00410-013-0875-4.

Kelman, I. \&Mather, T.A. (2008) Living with Volcanoes: The sustainable livelihoods approach for volcano-related opportunities. Science Direct, 172, pp.189-198. doi: http:// doi.org/10.1016/j. jvolgeores.2007.12.007.

Maritimo, F., Wardhani, P.I., \& Wardhana, G.M.K. (2014) Potensi Lahar di Lereng Gunungapi Kelud Pasca-Erupsi 2014, in: Sartohadi, J. \& Pratiwi, E.S. (Eds.). Pengelolaan Bencana Kegunungapian Kelud pada Periode Krisis Erupsi 2014, Pustaka Pelajar, Yogyakarta. pp. 52-76.

Marti, J. \& Ernst, G.J. (2005) Volcanoes and The Enviroment, Cambridge University Press, New York.

Pratomo, I. (2006) Klasifikasi gunungapi aktif Indonesia, studi kasus dari beberapa letusan gunungapi dalam sejarah, Jurnal Geologi Indonesia, 4, pp. 209-227.

Thouret, J.C., Abdurachman, K., Bourdier, J.L., Bronto, S. (1998) Origin, characteristics, and behaviour of lahars following the 1990 eruption of Kelud volcano, eastern Java (Indonesia). Bulletin of Volcanology, Vol. 59, No. 7, pp. 460-480. doi:10.1007/s004450050204

Tilling, R. I. (2005) Volcano Hazards, in: Ernst, G \&Marti, J. (Eds.) Volcanoes and The Environment, Cambridge University Press, Amerika.

Tilling, R.I \& Lipman, P.W. (1993) Lessons in Reducing Volcanic Risk, Nature,364, pp. 277-280.

Twigg, J. (2004). Good Practice Review No. 9 Disaster risk reduction: Mitigation and preparedness in development and emergency programming.

Wardhani, P.I. (2013) Mekanisme Bertahan Masyarakat Tengger di Probolinggo terhadap Erupsi Gunung Bromo Tahun 2010-2011 (Unpublished master thesis). Universitas Gadjah Mada, Yogyakarta.

Zaennudin, A. (2009) Prakiraan Bahaya Erupsi Gunung Kelud. Bulletin Vulkanologi dan Bencana Geologi, 4, pp.1-17. 